\title{
EXPERIENCES OF WOMEN WITH INFERTILITY ATTENDING GYNAE OPD OF TERTIARY HOSPITAL OF RUPANDEHI
}

Saraj Gurung, ${ }^{1}$ Sulochana Ghimire, ${ }^{1}$ Anuja Kachapati ${ }^{1}$

\begin{abstract}
INTRODUCTION

One of the most important and underappreciated reproductive health problems in developing countries is the high rate of infertility and childlessness. The inability to have a child is frequently considered a personal tragedy affecting the entire family and even the local community.
\end{abstract}

\section{MATERIAL AND METHODS}

The descriptive phenomenological research design was used to explore experiences of women with infertility. Fifteen women with infertility were selected by purposive sampling technique. Data was collected through in-depth interview method using unstructured questionnaire and thematic analysis was done.

\section{RESULTS}

Among 15, 46.66\% of the participants had gynecological problems and $53.33 \%$ had medical problems such as hypothyroidism and hyperthyroidism. Thirty-three percentage of participants' spouse had problem of low sperm count and absence of sperm. Most of the participants and their spouses were under treatment. Sixty percentage of the participants had experienced psychosocial problems and $26.66 \%$ had experienced physical and sexual problems because of infertility.

\section{CONCLUSION}

It is concluded that participants are suffered mainly from psychosocial problems beside that physical and sexual problems. Cent percent of the participants were under treatment and majority of participants said they will try for conception until fertility seized. One third of participants spouse had problem of sperm. It is recommended to concerned authority of hospital to provide couple counseling regarding infertility.

KEY WORDS Infertility, Women, Physical problems, Psychosocial problems

1. Universal College of Nursing Sciences, UCMS, Siddharthanagar-1, Rupandehi, Nepal

DOI: http//doi.org/10.3126/jucms.v7i2.27142

For Correspondence

Ms. Saraj Gurung

Universal College of Nursing Sciences

UCMS, Siddharthanagar-1, Rupandehi, Nepal

Email:g.saraj@gmail.com 


\section{INTRODUCTION}

Infertility is a disease defined by the failure to achieve a clinical pregnancy after 12 months or more of regular unprotected sexual intercourse. ${ }^{1}$ WHO (2010) estimates 48.5 million couples worldwide were unable to have a child. About 1.9 percent of women aged 20-44 who wanted a child were unable to have their first live birth. ${ }^{2}$

Infertility is associated with discrimination from family members and neighbors, negative mental health consequences, murder and suicide. ${ }^{3}$ In Nepal infertility is not only a problem of the couple but it is a problem of family and society ${ }^{4}$. Although infertility poses a big problem, it still remains widely neglected. ${ }^{5}$

Many wives tend to blame themselves irrespective of who may responsible. In some cases women are threatened with another marriage/divorce and many fear of loss of social and economic security. They could be victim of violence, abuse and social exclusion. Some husbands are supportive and defend their wives against family pressure or criticism. ${ }^{6}$ The physical and psychological suffering and infertility is unclear. A study of Nepal reveals that informants experienced any one or all form of abuse. ${ }^{8}$

\section{MATERIAL AND METHODS}

The phenomenological research design was used to explore lived experiences of women with infertility. The population of the study consisted of 15 women with infertility attending gynae out patient department of Universal College of Medical Sciences (UCMS)-Teaching Hospital (TH), Bhairahawa, Rupandehi. Sample of was selected by non probability sampling technique. Data was collected through an in-depth interview method with use of unstructured questionnaire.

Before proceeding data collection administrative and ethical approval was obtained from UCMS-TH and IRC of UCMS. Written informed consent was taken from each participant by clarifying the objective of the study. Participants were assured for the confidentiality of the information given by them and only used for the study purpose. Verbal and non-verbal expression of the participants was noted while interviewing. The in-depth interview was done in period of May $22^{\text {nd }} 2018$ to $3^{\text {rd }}$ June 2019.

After the interview all the field notes were labeled with code numbers. The verbatim information given by participants was transcribed and translated into English for the reporting. After collection of data, thematic analysis was done.

\section{RESULTS}

Regarding socio-demographic variables, $60 \%$ of participants were between the age of 26-30 years. Ninety-three percentage of the participants were literate, $47 \%$ were from out of Rupandehi and 20\% were from India. Sixty percentage of the participants lived in joint family. Fifty-three percentage participants' spouse was between the age of 31-40 years and $100 \%$ was literate.

Out of 15 respondents, $60 \%$ of the participants got married at the age of $15-19$ years and $53.33 \%$ of the participants had 6-9 years of marriage duration. Fifty-three percentage of the participants were trying to conceive from 1-5 years and $46.66 \%$ had started from 6-10 years. Sixty-seven percentage of the participants had started treatment from 2 months-2 years and $33.33 \%$ of the participants had started from 3-4 years. Information regarding gynecological and medical problems and types of treatment is shown in Table 1.

Table 1. Participants' gynecological and medical problems and types of treatment

\begin{tabular}{|c|c|c|c|c|c|}
\hline $\begin{array}{l}\text { Case } \\
\text { No. }\end{array}$ & $\begin{array}{l}\text { Gynecological } \\
\text { problem }\end{array}$ & $\begin{array}{l}\text { Medical } \\
\text { problem }\end{array}$ & $\begin{array}{c}\text { Treatment of } \\
\text { problems }\end{array}$ & $\begin{array}{l}\text { Treatment done in } \\
\text { previous } \\
\text { (place) }\end{array}$ & $\begin{array}{l}\text { Traditional } \\
\text { Practice }\end{array}$ \\
\hline 01. & $\begin{array}{l}\text { Fallopian tube } \\
\text { blocked (one side) } \\
\text { Polycystic ovary } \\
\text { syndrome }\end{array}$ & $\begin{array}{l}\text { Hypothyroidism } \\
\text { (from } 10 \text { years), } \\
\text { Diabetes } \\
\text { Mellitus } \\
\text { (6 month back) }\end{array}$ & $\begin{array}{l}\text { Under treatment of } \\
\text { hypothyroidism, } \\
\text { diabetes mellitus and } \\
\text { treatment for infertility }\end{array}$ & $\begin{array}{l}\text { India, Other Medical } \\
\text { College, Private } \\
\text { clinic Bhairahawa }\end{array}$ & $\begin{array}{l}\text { Do not believe on } \\
\text { traditional healing }\end{array}$ \\
\hline 02. & $\begin{array}{l}\text { Leucorrhoea, } \\
\text { irregular } \\
\text { menstruation }\end{array}$ & No & $\begin{array}{l}\text { Treatment of } \\
\text { leucorrhoea and } 2 \text { times } \\
\text { IUI tried but did not } \\
\text { occur ovulation and } \\
\text { planning to go Delhi for } \\
\text { IVF }\end{array}$ & $\begin{array}{l}\text { Butwal, India and } \\
\text { Kathmandu }\end{array}$ & $\begin{array}{l}\text { Believes on god, } \\
\text { going temple and } \\
\text { keeping fasting }\end{array}$ \\
\hline 03. & No & $\begin{array}{l}\text { Hypothyroidism } \\
\text { (from } 2 \text { years) }\end{array}$ & $\begin{array}{l}\text { Under medication of } \\
\text { hypothyroidism }\end{array}$ & UCMS-TH & $\begin{array}{l}\text { Ayurvedic } \\
\text { treatment done for } \\
2 \text { years and went } \\
\text { Mosk Ajmer, } \\
\text { India for religious } \\
\text { activity }\end{array}$ \\
\hline 04. & $\begin{array}{l}\text { Polycystic ovary } \\
\text { syndrome }\end{array}$ & Hypothyroidism & $\begin{array}{l}\text { Under treatment of } \\
\text { hypothyroidism }\end{array}$ & UCMS-TH & $\begin{array}{l}\text { Religious } \\
\text { activities }\end{array}$ \\
\hline 05. & No & $\begin{array}{l}\text { Vertigo and } \\
\text { fainting }\end{array}$ & $\begin{array}{l}\text { Under treatment of } \\
\text { irregular menstruation }\end{array}$ & Local private clinic & $\begin{array}{l}\text { Believes on god, } \\
\text { worshipping }\end{array}$ \\
\hline 06. & $\begin{array}{l}\text { Leucorrhoea and } \\
\text { intramural uterine } \\
\text { fibroid }\end{array}$ & No & Under treatment & $\begin{array}{l}\text { Bharatpur hospital } \\
\text { and UCMS-TH }\end{array}$ & Did not believe \\
\hline 07. & No & Pain abdomen & $\begin{array}{l}\text { Treatment of pain } \\
\text { abdomen }\end{array}$ & $\begin{array}{l}\text { Local clinic, } \\
\text { UCMS-TH }\end{array}$ & $\begin{array}{l}\text { Went faith healer; } \\
\text { witch craft has } \\
\text { tied her womb }\end{array}$ \\
\hline 08. & No & No & No & $\begin{array}{l}2^{\text {nd }} \text { visit in UCMS } \\
\mathrm{TH}\end{array}$ & Do not believe \\
\hline 09. & No & Hypothyroidism & $\begin{array}{l}\text { Under medication } \\
\text { (from } 2 \text { years) }\end{array}$ & $\begin{array}{l}\text { Other Medical } \\
\text { College } \\
\text { UCMS-TH }\end{array}$ & $\begin{array}{l}\text { Worshipping and } \\
\text { praying the god }\end{array}$ \\
\hline 10. & No & No & No & UCMS-TH & $\begin{array}{l}\text { Worshipping and } \\
\text { praying the god }\end{array}$ \\
\hline 11. & $\begin{array}{l}\text { Irregular } \\
\text { menstruation since } \\
3 \text { year }\end{array}$ & $\begin{array}{l}\text { Hypothyroidism } \\
\text { from } 6 \text { years }\end{array}$ & Under medication & India & $\begin{array}{l}\text { Worshipping and } \\
\text { praying the god }\end{array}$ \\
\hline 12. & $\begin{array}{l}\text { Irregular and } \\
\text { dysmenorrhea }\end{array}$ & Hyperthyroidism & Under medication & UCMS-TH & Do not believe \\
\hline 13. & Ovarian cyst & No & & - & $\begin{array}{l}\text { Believes in Faith } \\
\text { healer }\end{array}$ \\
\hline 14. & No & No & & $\begin{array}{l}\text { Butwal Nursing } \\
\text { Home }\end{array}$ & $\begin{array}{l}\text { Believes in Faith } \\
\text { healer }\end{array}$ \\
\hline 15. & No & No & & - & Do not believe \\
\hline
\end{tabular}

Thirty three percentage of the participants spouse had sperm 
problem, among them, $60 \%$ had low sperm count and $20 \%$ had normal sperm count but only $15 \%$ sperm abnormal and azoospermia and low testosterone respectively. Eighty percentage of the participants' spouse with sperm problem were under treatment.

Out of 15 respondents all of them have encountered problems because of infertility which is shown in Table 2

\section{Table 2. Experiences of women with infertility}

\begin{tabular}{|c|c|c|c|c|c|}
\hline $\begin{array}{l}\text { Case } \\
\text { No. }\end{array}$ & $\begin{array}{l}\text { Physical } \\
\text { problems }\end{array}$ & $\begin{array}{l}\text { Psycho-social } \\
\text { problems }\end{array}$ & Financial problems & $\begin{array}{l}\text { Problems in sexual and } \\
\text { marital relationship }\end{array}$ & Facial expression \\
\hline 01. & No & Back biting & $\begin{array}{l}\text { Couple is borrowing } \\
\text { money for } \\
\text { Treatment }\end{array}$ & Normal & Sad \\
\hline 02. & Work load & $\begin{array}{l}\text { Back biting, } \\
\text { threaten for } \\
\text { second } \\
\text { marriage of son }\end{array}$ & No & $\begin{array}{l}\text { Husband insist to have sex } \\
\text { even she is not ready }\end{array}$ & Stressed and upset \\
\hline 03. & Work load & Back biting & $\begin{array}{l}\text { Mother gives money } \\
\text { and insists for } \\
\text { treatment of } \\
\text { infertility }\end{array}$ & $\begin{array}{l}\text { Husband insist to have sex } \\
\text { everyday with the hope of } \\
\text { conception }\end{array}$ & she seemed normal \\
\hline 04. & No & $\begin{array}{l}\text { Query for not } \\
\text { having baby }\end{array}$ & No & $\begin{array}{l}\text { Good but sometimes she } \\
\text { avoids sexual contact } \\
\text { because of anxiety }\end{array}$ & $\begin{array}{l}\text { Sad (crying in } \\
\text { interview time) }\end{array}$ \\
\hline 05. & No & No & No & $\begin{array}{l}\text { Excess sexual relation but } \\
\text { sometimes she does not } \\
\text { want }\end{array}$ & $\begin{array}{l}\text { Sad/depressed } \\
\text { (both husband and } \\
\text { wife crying) }\end{array}$ \\
\hline 06. & No & No & No & Good & Seemed normal \\
\hline 07. & No & No & No & Good & Seemed normal \\
\hline 08. & No & No & No & Good & $\mathrm{Sad}$ \\
\hline 09. & Work load & Back biting & No & Normal & Sad \\
\hline 10. & Work load & $\begin{array}{l}\text { Back biting, } \\
\text { give pressure to } \\
\text { have baby }\end{array}$ & No & Normal & Stressed \\
\hline 11. & No & $\begin{array}{l}\text { Give pressure to } \\
\text { have baby }\end{array}$ & No & Normal & Sad \\
\hline 12. & No & $\begin{array}{l}\text { Give pressure to } \\
\text { have baby }\end{array}$ & No & Normal & Sad \\
\hline 13. & No & No & No & Normal & $\mathrm{Sad}$ \\
\hline 14. & No & $\begin{array}{l}\text { Blaming for not } \\
\text { having baby }\end{array}$ & No & Good & Sad and stressed \\
\hline 15. & No & No & No & Normal & Sad and stressed \\
\hline
\end{tabular}

Forty-seven percentage of the participants expressed about the perpetrator of their violence among them, $71.42 \%$ said mother-in-law and $14.28 \%$ said sister in-law. Sixty seven percentage of the participants said they used coping mechanisms, among them $60 \%$ said crying and $10 \%$ said keeping fasting and worshipping, not eating food, praying and caring of brother in-law' children respectively. Eighty seven percentage expressed about their support system, among them, 53.84\% and 7.69\% said that their husband and sisterin-law were supportive. Sixty-seven percentage said they will continue treatment of infertility and try for conception until fertility seized, and $13.33 \%$ said that they are thinking of adoption of son of own family member.

\section{DISCUSSION}

Gender inequality

The study revealed that male domination is high in participants' family. Husband and father in-law were head of family. Gender inequality is the major factor of experiencing problems in women with infertility. One participant's husband had problem of normal sperm count with $15 \%$ active; he had not disclosed it to his family but participant was blamed for infertility. A study of Iran shows; in many cultures, womanhood is defined as through motherhood, and infertile women usually carry the blame for the couples' inability to conceive.

\section{Age of women}

The age of women is a factor of creating problems in infertility cases. More pressure is given to high aged woman to have a child because of short fertility period. Researchers found nine participants were between the ages of 26-30 years among them seven participants had experienced emotional problems because of infertility.

Family structure

Three participants who were living in joint family, they had work load of household chores. Other family member used to think childless woman has a time because they do not need to involve in caring of children and five participants living in joint family had experienced emotional problems.

\section{Duration of marriage}

Duration of marriage is one of the important factors in experience of problems with infertility. Eight participants had 6-9 years of duration of marriage had experienced emotional problems. Aged participants with high duration of marriage seemed more worried and stressed than participants of young age and with less duration of marriage.

Only one son in family

In Nepalese society offspring of family is necessary and very important. Two participants' whose husband were only one son of family, then they were in a pressure to have a child. One of the participant said her mother in-law threatened her for second marriage of her husband. The study shows children are highly desired, parenthood is culturally mandatory and childlessness is socially unacceptable. ${ }^{3}$

\section{Infertility problem in spouse and male member in family}

Different literatures show that infertility can also be caused by problems related to male. In this study, five participants' husband had problem in sperm count. Those family members who knew that the problem is in their son are not giving pressure to have child or blaming to daughter-in-law. 


\section{Treatment of Infertility}

The study found $60 \%$ of the participants were trying to conceive from 1-5 years. Forty percentage of participants had done treatment in India, Kathmandu and Chitwan. Now they were taking treatment in UCMS-TH. One participant had done ayurvedic treatment for two years and one had treated with faith healer before coming UCMS-TH. This study found that four participants' husband had problem of sperm count and they were under treatment. In some cultures, traditional or magical treatment is employed for treatment of infertility, but in other cultures, the problem of infertility is solved through adopting a child, remarriage, or even divorce. ${ }^{10}$ A study shows nowadays, usually couple visits to hospital and find out who has fertility problems and they get treatment according to available health services based on their economic status. ${ }^{8}$

Psychological status

During in-depth interview, $80 \%$ of participants were seemed sad, stressed upset and depressed. During the study, it has been reported that infertile women are deeply worried and feel alone because their situations and securities are affected by the experience of infertility. ${ }^{6}$ In an Iran study, it was found that couples' relatives limited relations with the infertile couples. Intervention of relatives, especially of the husband's family, negative attitudes towards them and the behaviours of those around them (e.g. family, friends, and neighbours) cause psychological problems for infertile couples. ${ }^{11}$

Sexual and marital relationship

Infertility can lead to stress in any type of relationship and it's a common cause of problems in relationship. The study found that four participants' husband insisted to have continued and excess sexual contact by hoping conception would occur. Two of them did not feel ready for sexual contact all the time, when their husband insists. The study of Iran shows, family status, especially child bearing, is very important and valuable. Having a child stabilizes the family and increases marital satisfaction. $^{12}$

\section{Coping mechanism}

People use different coping mechanisms when they are in stress. Researchers found that participants used various mechanisms to cope the stress of infertility. Thirteen participants were using coping mechanisms such as coping mechanism.

\section{Support system}

The social support builds people up during times of stress and often gives them the strength to carry on and even thrive. Seven participants' husbands were supportive, five participants' in-laws family members were supportive, four participants' mother and siblings were supportive.

\section{Future plan}

Researchers tried to find future plan of participants in case of not able to become pregnant. Two participants said they will adopt child of own family member (brother and brother inlaw). Ten participants said they will continue treatment of infertility and trying for conception until fertility seized. The study of Pakistan shows; childless women wish to have a child and it does not matter if it is a male or a female one. For them, a child, regardless of his sex, will bring them honor, respect and recognition as fully adults. ${ }^{3}$

\section{CONCLUSION}

Infertility is perceived and experienced as a negative situation that is related to tension within the family, constant health seeking and disappointments regarding treatment and their outcomes. In our society, infertile women are still victimized from all spare of their personal and social life although infertility is a biomedical cause.

\section{ACKNOWLEDGEMENTS}

Researchers deeply express their heartfelt thanks to all who participated in the study for immense support and cooperation. Researchers express their deep and sincere gratitude to all those experts for their valuable judgment, constructive feedbacks and enlightening suggestions throughout the study.

\section{REFERENCES}

1. Zegers-Hochschild F, Adamson GD, de Mouzon J, Ishihara O, Mansour R, Nygren K, Sullivan E, Van der Poel S. The international committee for monitoring assisted reproductive technology (ICMART) and the world health organization (WHO) revised glossary on ART terminology, 2009. Human Reproduction. 2009 Oct 4;24(11):2683-7.

2. Charlotte Warren-Gash. Worldwide infertility rates unchanged in 20 years says World health organization. 2013 Jan 7.

3. Schmidt Stiedenroth KN. Infertility in Pakistan: Experience and Health Seeking Behavior among Baloch Women in a Karachi Slum (Master's thesis).

4. Http://www.infertilitynepal.com/2012/02/normal-0-false-falsefalse-en-us-X-none.html

5. Daar AS, Merali Z. Infertility and social suffering: the case of ART in developing countries. Current Practices and Controversies in Assisted Reproduction. 2002;15:21.

6. Widge A, Cleland J. The public sector's role in infertility management in India. Health Policy and Planning. 2009 Jan 29; 24(2):108-15. 
7. Cwikel J, Gidron Y, Sheiner E. Psychological interactions with infertility among women. European Journal of Obstetrics \& Gynecology and Reproductive Biology. 2004 Dec 1;117(2):12631.

8. Bista B. Lived Experience of Infertility among Community Dwelling Infertile Women. Journal of Nobel Medical College. 2015 Sep 1;4(1):46-56

9. Behboodi-moghadam Z, Salsali M, Eftekhar-ardabily $\mathrm{H}$, Vaismoradi M, Ramezanzadeh F. Experiences of infertility through the lens of Iranian infertile women: a qualitative study. Japan Journal of Nursing Science. 2013 Jun 1;10(1):41-6.

10. Even E. (2004). A global perspective on infertility: An under recognized public health issue. University NC Newsletter, 18, $1-39$.

11. Ramezanzadeh F., Aghssa M. M., Abedinia N., Zayeri F., Khanafshar, N. Shariat M. et al. (2004). A survey of relationship between anxiety, depression and duration of infertility. BMC Women's Health, 4, 9-15.

12. Eftekhar-Ardabily H., Behboodi-Moghadam Z., Salsali M., Ramezanzadeh F. and Nedjat S . Prevalence and risk factors for domestic violence against infertile women in an Iranian setting. International Journal of Gynecology and Obstetrics. 2011;112, 15-17. 